\title{
Climate change and cultural resilience in late pre-Columbian Amazonia
}

Jonas Gregorio de Souza ${ }^{1}$, Mark Robinson², S. Yoshi Maezumi³, José Capriles ${ }^{4}$, Julie A. Hoggarth $^{5}$, Umberto Lombardo ${ }^{6}$, Valdir Felipe Novello ${ }^{7}$, James Apaéstegui ${ }^{8}$, Bronwen Whitney ${ }^{9}$, Dunia Urrego ${ }^{2}$, Daiana Travassos Alves ${ }^{10}$, Stephen Rostain ${ }^{11}$, Mitchell J. Power ${ }^{12}$, Francis E. Mayle $_{13}$, Francisco William da Cruz Jr. ${ }^{7}$, Henry Hooghiemstra ${ }^{14}$, José Iriarte ${ }^{2}$

${ }^{1}$ Universitat Pompeu Fabra, Barcelona, Spain

2 University of Exeter, Exeter, UK

${ }^{3}$ The University of the West Indies at Mona, Kingston, Jamaica

${ }^{4}$ Pennsylvania State University, Pennsylvania, US

${ }^{5}$ Baylor University, Waco, US

${ }^{6}$ Universität Bern, Bern, Switzerland

${ }^{7}$ Universidade de São Paulo, São Paulo, Brazil

8 Instituto Geofísico del Peru

${ }^{9}$ Northumbria University, Newcastle, UK

${ }^{10}$ Universidade Federal do Pará, Belém, Brazil

${ }^{11}$ French National Centre for Scientific Research, Paris, France

12 The University of Utah, Salt Lake City, US

${ }^{13}$ University of Reading, Reading, UK

${ }^{14}$ Universiteit van Amsterdam, Amsterdam, Netherlands

\begin{abstract}
The long term response of ancient societies to climate change has been a matter of global debate. Until recently, the lack of integrative studies between archaeological, palaeoecological, and palaeoclimatological data had prevented an evaluation of the relationship between climate change, distinct subsistence strategies, and cultural transformations across the largest rainforest of the world, Amazonia. Here, we review the most relevant cultural changes seen in the archaeological record of six different regions within Greater Amazonia during late pre-Columbian times. We compare the chronology of those cultural transitions with high-resolution regional palaeoclimate proxies, showing that, while some societies faced major reorganisation during periods of climate change, others were unaffected and even flourished. We propose that societies with intensive, specialised land-use systems were vulnerable to transient climate change. In contrast, land-use systems that relied primarily on polyculture agroforestry, resulting in the formation of enriched forests and fertile Amazonian Dark Earths in the long term, were more resilient to climate change.
\end{abstract}

\section{Introduction}

The consequences of the European encounter on the indigenous populations of the Americas cannot be overstated. Some estimate $90-95 \%$ population decline due to epidemics and violence $^{1,2}$. With a population of up to 10 million inhabitants ${ }^{3,4}$ now postulated for Amazonia in late pre-Columbian times, it is likely that the demographic losses following the European contact reshaped landscapes and cultural geographies across the region. Prevailing popular opinion is 
that indigenous cultures in the Americas were experiencing a trajectory of growth and increasing complexity that was interrupted by the arrival of Europeans, but periods of oscillation are expected to have occurred. In Amazonia, this question remains unresolved. Elsewhere in the Americas, there is mounting evidence of population declines and climate-driven collapse of complex societies preceding the Columbian encounter - from the Pueblos of the US Southwest ${ }^{5}$, through the Classic Maya in Mesoamerica ${ }^{6,7}$, to the Tiwanaku state in the Andean highlands ${ }^{8,9}$. In other parts of the globe, the vulnerability or resilience of ancient societies to climate change have been shown to be mediated by distinct economic practices ${ }^{10}$. Yet, little is known about pre-Columbian human responses to climate change in Amazonia.

Here, we explore spatio-temporal patterns of climate and culture change in Amazonia to assess the role of distinct land-use systems in vulnerability or resilience to climate change. We review transformations observed in the archaeological record across six regions where research has been more intensive, chronologies are robust (Supplementary Note 1, Supplementary Tables 1-6), and pre-Columbian land-use patterns are best understood (Figure 1, Table 1). We compare the archaeology of each region with palaeoecological records (pollen, charcoal). Given the heterogeneity of local climatic regimes, we consider each region separately and highlight the broader cultural and climatic patterns that emerged during the late Holocene in Amazonia.

We argue that patterns of cultural change in pre-Columbian Amazonia can be understood from the perspective of risk management strategies and adaptive cycles. Two land-use strategies have been identified among late pre-Columbian Amazonian societies. One involves maximisation, specialisation in public infrastructure, and immediate impact. The other focuses on cumulative, long-term impact through diversification, polyculture agroforestry and anthropogenic soil formation. From the point of view of risk management, maximisation strategies lead to short-term benefits in unstable environments, but result in heavier losses during climatic oscillations, whereas low intensity polyculture is more resilient to external stressors. The flexibility, or lack thereof, of these systems explains the decline of some societies and not others according to their economic base ${ }^{11}$. We suggest that the societies that collapsed under climate change were approaching the end of an adaptive cycle that progressed through phases of growth, accumulation, restructuring and renewal. These societies had accumulated rigidities, and were less likely to absorb unforeseen disturbances, resulting in dramatic transformation ${ }^{12-14}$. 


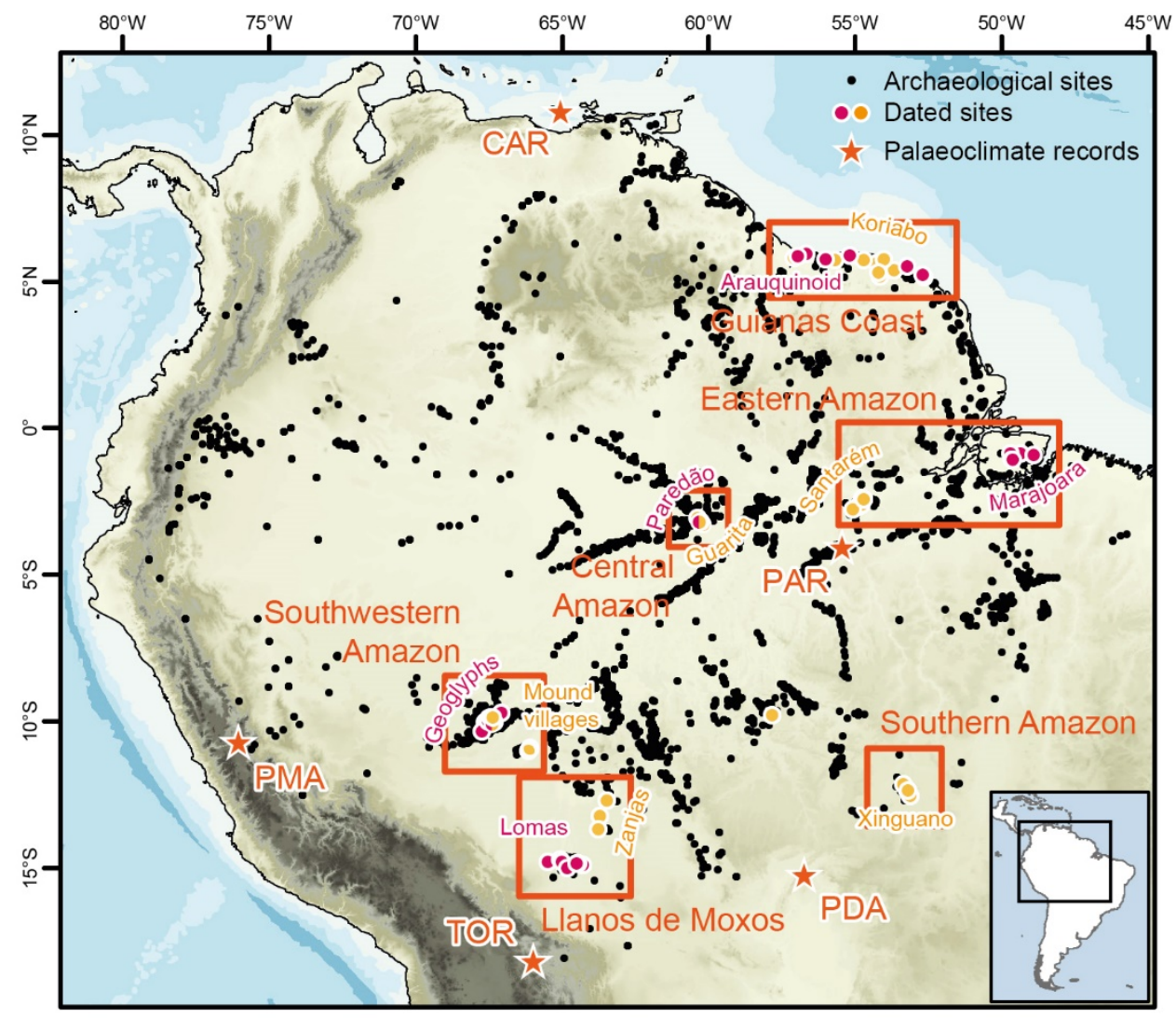

Figure 1. Regions, archaeological sites ${ }^{15-17}$ and palaeoclimate records discussed in the text. CAR $=$ Cariaco Basin $^{18}$, PAR $=$ Paraíso Cave ${ }^{19}$, PMA $=$ Pumacocha Lake ${ }^{20}$, TOR $=$ Torotoro $^{21}$, PDA $=$ Pau d'Alho Cave ${ }^{22}$. Only the dated sites for the respective regions and cultures are shown. Colours of dated sites correspond to different regional archaeological cultures as they appear in Figure 3, and these are identified by labels using the same colour scheme. Dots with more than one colour represent multicomponent sites (occupied by more than one culture).

\begin{tabular}{|l|l|l|l|l|l|}
\hline Region & $\begin{array}{l}\text { Archaeologica } \\
\text { I tradition }\end{array}$ & $\begin{array}{l}\text { Time } \\
\text { period }\end{array}$ & $\begin{array}{l}\text { Socio- } \\
\text { political } \\
\text { organisation }\end{array}$ & Land use & References \\
\hline $\begin{array}{l}\text { Guianas } \\
\text { Coast }\end{array}$ & Arauquinoid & AD 650- & $\begin{array}{l}\text { Settlement } \\
\text { hierarchy of } \\
\text { residential } \\
\text { and } \\
\text { ceremonial } \\
\text { mounds, well- } \\
\text { defined } \\
\text { chiefdom } \\
\text { territories. }\end{array}$ & $\begin{array}{l}\text { Raised fields } \\
\text { for cultivation } \\
\text { of maize, } \\
\text { Cucurbita, } \\
\text { manioc. }\end{array}$ & $23-26$ \\
\hline
\end{tabular}




\begin{tabular}{|c|c|c|c|c|c|}
\hline & Koriabo & $\begin{array}{l}\text { AD 1000- } \\
1600\end{array}$ & $\begin{array}{l}\text { Reoccupation } \\
\text { of earlier sites }\end{array}$ & $\begin{array}{l}\text { Possible } \\
\text { ADE. }\end{array}$ & 23,27 \\
\hline \multirow[t]{2}{*}{$\begin{array}{l}\text { Eastern } \\
\text { Amazon }\end{array}$} & Marajoara & $\begin{array}{l}\text { AD 500- } \\
1200\end{array}$ & $\begin{array}{l}\text { Settlement } \\
\text { hierarchy of } \\
\text { residential } \\
\text { mounds, elite } \\
\text { burials and } \\
\text { prestige } \\
\text { ceramics. }\end{array}$ & $\begin{array}{l}\text { Ponds for } \\
\text { aquaculture, } \\
\text { no evidence } \\
\text { of maize. }\end{array}$ & $28-30$ \\
\hline & Santarém & $\begin{array}{l}\text { AD 1050- } \\
1650\end{array}$ & $\begin{array}{l}\text { Settlement } \\
\text { hierarchy is } \\
\text { debated. }\end{array}$ & $\begin{array}{l}\text { ADE } \\
\text { polyculture, } \\
\text { cultivation of } \\
\text { maize, } \\
\text { Cucurbita, } \\
\text { manioc and } \\
\text { sweet potato. }\end{array}$ & $31-36$ \\
\hline \multirow[t]{2}{*}{$\begin{array}{l}\text { Central } \\
\text { Amazon }\end{array}$} & Paredão & $\begin{array}{l}\text { AD 750- } \\
1250\end{array}$ & $\begin{array}{l}\text { Permanent } \\
\text { mound } \\
\text { villages. }\end{array}$ & $\begin{array}{l}\text { ADE } \\
\text { polyculture, } \\
\text { cultivation of } \\
\text { maize, yam, } \\
\text { Cucurbita. }\end{array}$ & $37-40$ \\
\hline & Guarita & $\begin{array}{l}\text { AD 1200- } \\
1600\end{array}$ & $\begin{array}{l}\text { Smaller } \\
\text { settlements, } \\
\text { rapid pan- } \\
\text { Amazonian } \\
\text { expansion. }\end{array}$ & ADE. & 41,42 \\
\hline \multirow[t]{2}{*}{$\begin{array}{l}\text { Southwestern } \\
\text { Amazon }\end{array}$} & Geoglyphs & $\begin{array}{l}400 \mathrm{BC}- \\
\text { AD } 950\end{array}$ & $\begin{array}{l}\text { Vacant } \\
\text { ceremonial } \\
\text { centres. }\end{array}$ & $\begin{array}{l}\text { Small } \\
\text { clearings in } \\
\text { bamboo } \\
\text { forest, } \\
\text { cultivation of } \\
\text { maize and } \\
\text { squash. }\end{array}$ & $30,43-46$ \\
\hline & Mound villages & $\begin{array}{l}\text { AD 1000- } \\
1650\end{array}$ & $N / A$ & $N / A$ & 47 \\
\hline
\end{tabular}




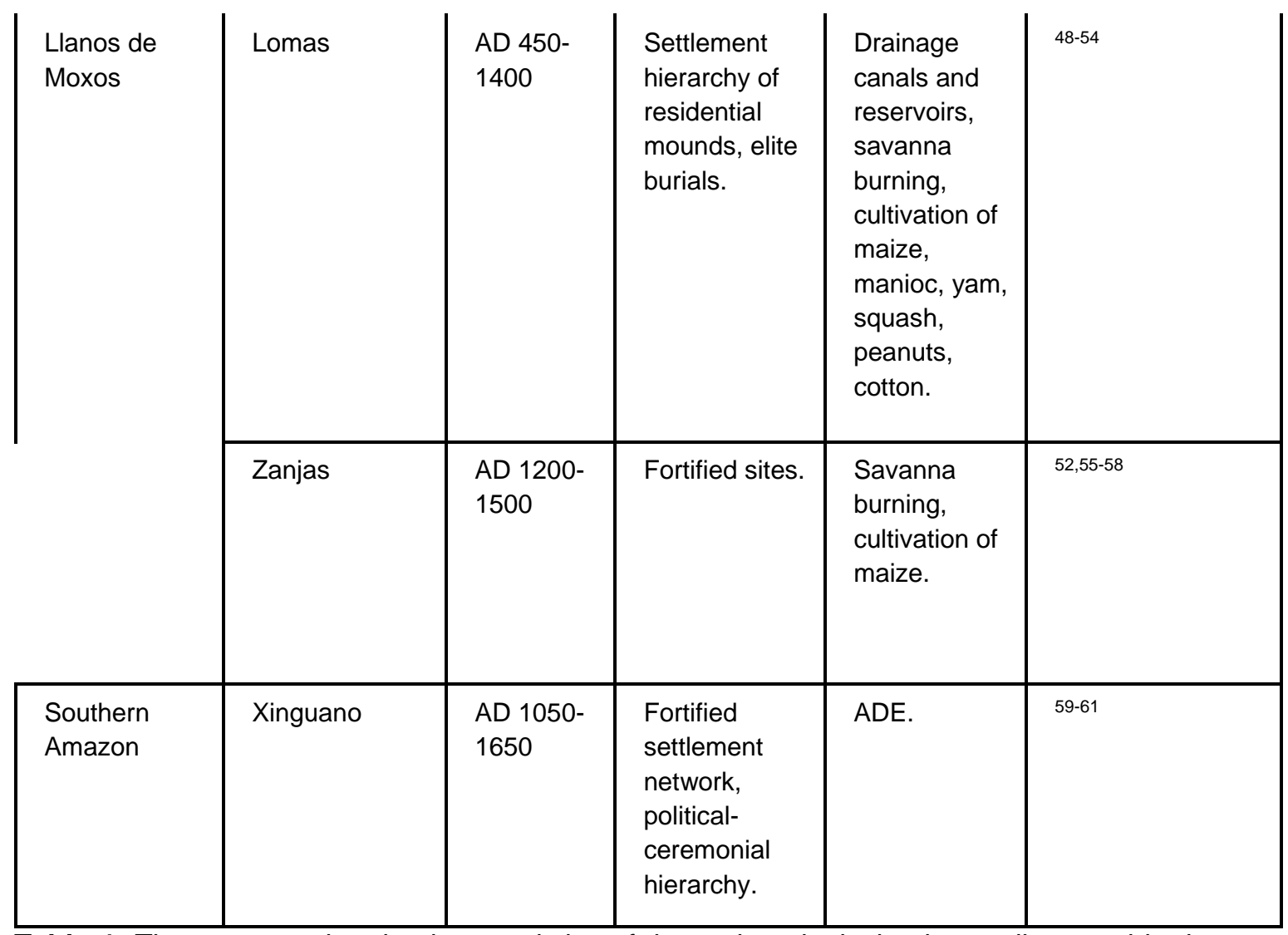

Table 1. Time span and main characteristics of the archaeological cultures discussed in the text. For a complete list of the radiocarbon dates, see Supplementary Tables 1-6.

\section{BOX 1: Synthesis and Integration of the Data}

Palaeoprecipitation: Metal concentration and oxygen isotopes, which respond to rainfall intensity and strength of the South American Summer Monsoon (SASM) respectively, were used as proxies for past precipitation. We selected the records with the highest resolution that were most representative and closest to the archaeological sites of the six selected regions. Palaeofire: Where sufficient data were present, existing lake sediment charcoal records were compiled using standard methodologies (see Supplementary Methods), to create regional charcoal curves to assess changes in past biomass burning with relative changes in climate, cultural phases and land use strategies. Cultural change: Periods of cultural change have been identified based on discontinuities in material culture (ceramic typologies) and in the architecture, size and distribution of settlements. These are thought to reflect either the replacement of one population by another or deep transformations within the same society over time. Figure 3 compares the chronology of cultural changes with the palaeoprecipitation records of each region discussed in the text.

\section{Climate dynamics in Amazonia}

Annual and daily temperature variability is low across the Amazon Basin. Mean annual temperatures vary between 18 and $23^{\circ} \mathrm{C}$. Rainfall over the Amazon Basin is sourced from two convective systems: the Intertropical Convergence Zone (ITCZ) and the South American Summer 
Monsoon (SASM) (Supplementary Discussion 2). The climate systems impacting Amazonia create a precipitation dipole at the borders of the monsoon, resulting in a climatic antiphase between western and eastern Amazon Basin ${ }^{62}$.

\section{Palaeoclimate records}

To characterise the palaeoclimatic conditions over the six regions, we used the following palaeoclimatic archives: metal concentration (\% Ti) from the sedimentary record from the Cariaco Basin $^{18}$ and oxygen isotope $\left(\delta^{18} \mathrm{O}\right)$ records from the Pumacocha Lake sediment core ${ }^{20}$ and stalagmites collected at Paraíso ${ }^{19}$, Pau d'Alho ${ }^{22}$ and Torotoro ${ }^{21}$ cave systems (Supplementary Methods).

All records document different climatic conditions over Amazonia during the periods known as the Medieval Climate Anomaly (MCA) AD 900-1250 and the Little Ice Age (LIA) AD $1450-1850^{63}$ (Figure 2). During the MCA, the ITCZ was shifted to the north of its current range, resulting in wet conditions over the Cariaco Basin and dry or neutral conditions in most of the sites under the influence of the SASM ${ }^{62,64}$ with the exception of Paraíso Cave and Torotoro ${ }^{21}$. The LIA period, in contrast, was characterised by dry conditions in the east (Paraíso Cave) and wet conditions in the west (Pumacocha Lake), with regions in between (Pau d'Alho Cave) not showing significant anomalies ${ }^{62}$. 


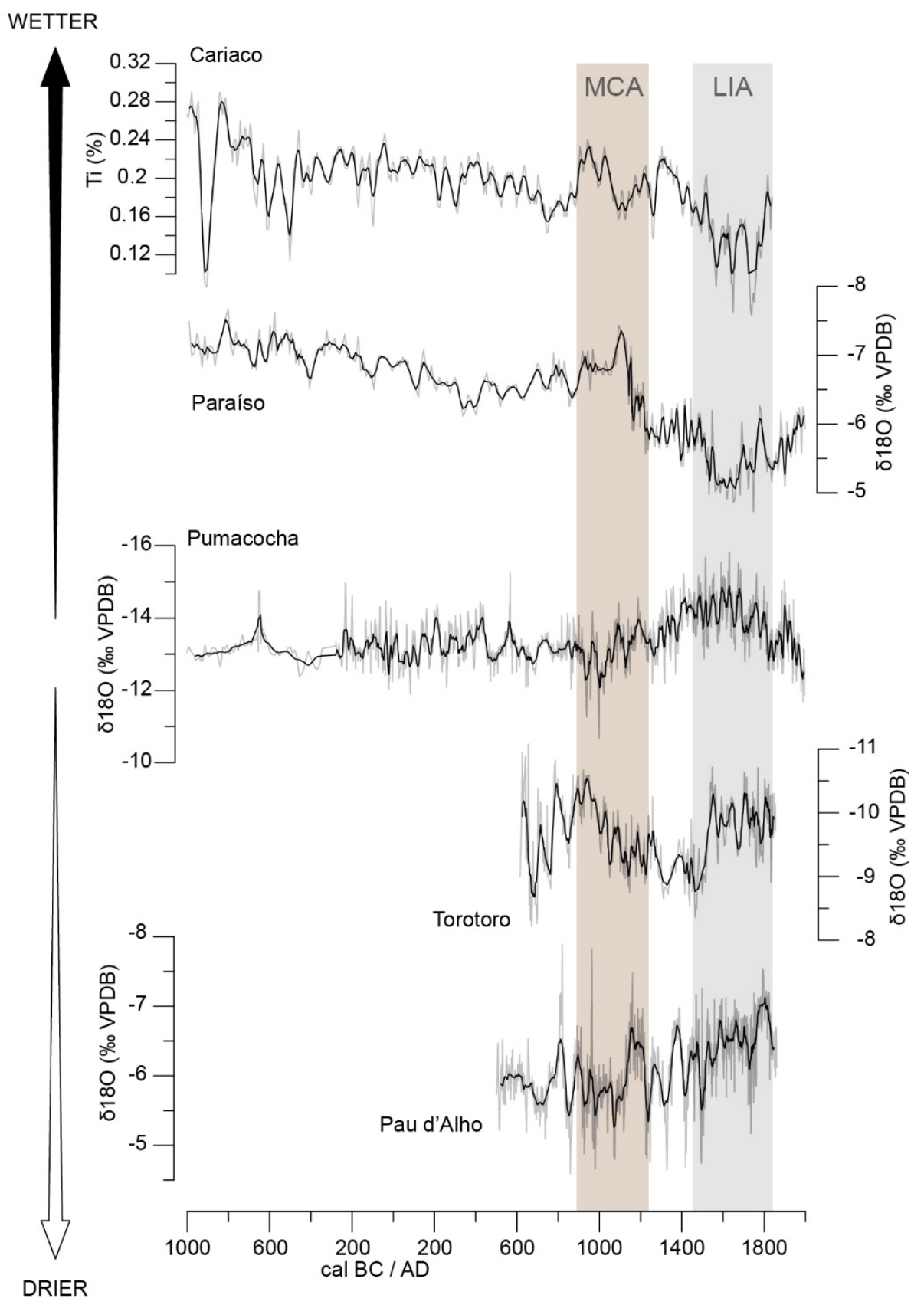

Figure 2. Palaeoclimate records discussed in the text (see location in Figure 1). MCA and LIA intervals are highlighted, demonstrating the antiphase between north and south of ITCZ and between western and eastern Amazon.

\section{The rise and fall of late pre-Columbian Amazonian cultures}

In what follows, we describe the most significant ruptures and transformations seen in the archaeological record of the six chosen regions. We focus on changes in settlement patterns and land use, when these are known, directing the reader to the Supplementary Discussion 1 for a summary of the material culture (ceramic typologies) associated with each culture. 
Guianas Coast. In this region, the most important transition in late pre-Columbian times is the breakdown in socio-political complexity of the coastal Arauquinoid societies, concomitant with the expansion of the inland Koriabo tradition $\sim A D 1300$ (Figure 3a). From Suriname to French Guyana, the Arauquinoid terraformed entire landscapes in coastal savannas starting $\sim A D$ $700^{23,24}$. Raised fields cover $\sim 3000$ ha in French Guyana ${ }^{23}$, with phytolith, starch grain and stable isotope evidence documenting the cultivation of maize, squash and manioc ${ }^{25,26}$. Charcoal records suggest that fire was used to a limited extent in land management ${ }^{65}$.

At the peak of the Arauquinoid occupation, the coast was divided into territories centered around large platform mounds with ceremonial and domestic functions ${ }^{23,24}$. Residential mounds were surrounded by a network of roads and agricultural earthworks that extended for up to $5 \mathrm{~km}$, with an estimated population of over 1000 inhabitants ${ }^{23}$. The disruption of the Arauquinoid regional organisation began $\sim A D 1300$, a period of upheavals marked by the spread of the Koriabo tradition. The earliest Koriabo sites are inland, with a progressive expansion towards the coast. Synchronicity between the Arauquinoid demise and the Koriabo expansion is clear across the Guianas Coast, especially along its western extent, where Arauquinoid earthwork density and complexity had been highest, whereas in the eastern sector there is continuity, interaction and emergence of hybrid traditions ${ }^{23}$.

Climate change, documented in the Cariaco Basin record, could have been the ultimate driver of the Arauquinoid decline (Figure 3a). Raised fields provide better drainage and moisture retention, allowing increased agricultural production in a region subject to a long rainy season and severe dry season ${ }^{66}$. If the Arauquinoid agricultural system was reliant on predictable seasonal precipitation, it is likely that their subsistence base was vulnerable to climate instability. The decline of mound centres AD 1300 could have been instigated by prolonged droughts documented in the palaeoclimate records. Alternatively, pressure from the Koriabo expansion itself could have been responsible for conflicts leading to the Arauquinoid demise, or at least accelerating a process triggered by climate change.

Eastern Amazon. Major transformations in late pre-Columbian eastern Amazon are highlighted by the decline of complex polities on Marajó Island, and the rise of Santarém culture in the lower Tapajós (Figure 3b).

One of the best documented archaeological cultures of Amazonia developed on Marajó Island $\sim A D$ 400. Archaeological evidence suggests a stratified society at the peak of the Marajoara phase $\sim A D$ 700-1100. The elite lived on large mounds, controlling access to prestige ceramics and water-management systems ${ }^{28,30,67}$. Mounds in the flooded savannas reached -3 ha in area and $7 \mathrm{~m}$ height. Population estimates are of up to 2000 for a mound group ${ }^{28,29}$. Unlike the Arauquinoid, there is no evidence that the subsistence of the Marajoara depended on cultivated plants. Macro-botanical remains of maize are absent ${ }^{28}$ and human bone isotopic values indicate a diet based on non-domesticated $\mathrm{C}_{3}$ plants and aquatic resources ${ }^{68}$. Marajoara earthworks include ponds for management of aquatic fauna ${ }^{29}$.

The disintegration of Marajoara chiefdoms AD 1200 led to abrupt changes in settlement patterns and material culture. Mound use declines, hierarchies between settlements disappear, elaborate urn burials are abandoned, and the polychrome Marajoara style becomes intermixed with foreign traditions ${ }^{29,69}$. The arrival of the Aruã nomadic foragers during this period has led to 
suggestions that the Aruã may have played a role in the Marajoara demise ${ }^{29}$. As in the Arauquinoid case, it is possible that the arrival of outsiders contributed to a process initiated by climate change.

While the Marajoara culture was in decline, another was flourishing in the lower Tapajós River. The Santarém culture, known for its elaborate effigy vessels, was established AD 1100. Comprising an area of $23,000 \mathrm{~km}^{2}$, over a hundred sites have been recorded, extending for hundreds of miles along river bluffs and interior plateaus. Historical accounts describe a chiefdom with a "noble class"31,32, but there is little archaeological evidence of social stratification" ${ }^{33-35}$. Virtually all sites are composed of anthropogenically modified Amazonian Dark Earth (ADE) ${ }^{34}$. Recent pollen and phytolith data suggest a diverse land-use strategy based on polyculture agroforestry, with the cultivation of maize, sweet potato, squash and manioc combined with the enrichment of forests with edible species ${ }^{36}$.

The Paraíso cave speleothem record provides a high-resolution proxy for precipitation changes in eastern Amazon ${ }^{19,70}$ (Figure 3b). An increase in $\delta^{18} \mathrm{O}$ values following $\sim A D 1100$ shows that the dissolution of the Marajoara chiefdoms coincided with decreased precipitation. A relationship between decreased river discharges, increased water salinity, and the decline of the aquaculture-based Marajoara chiefdoms during this period has previously been suggested based on pollen data ${ }^{71}$. High-status mounds are closely associated with water-management facilities, suggesting monopolisation of resources and surplus production by the elite ${ }^{29}$. Therefore, the landuse strategies that sustained the Marajoara chiefdoms would have been sensitive to prolonged droughts. During the same period, archaeological data indicate that the Santarém culture flourished in spite of the drier conditions. The regional charcoal curve for eastern Amazon shows an increase in fire activity synchronous with the rise of the Santarém culture and the Marajoara decline. Regional-scale fire activity during the apex of the Santarém culture has been attributed to human as opposed to climate drivers ${ }^{36}$ (Figure 3b). As will be discussed at the end of the paper, we suggest that the flourishing of Santarém in spite of climate change may be explained by greater resilience offered by an economy based on polyculture agroforestry ${ }^{36}$.

Central Amazon. At the confluence of the Negro and Solimões rivers, the millennium preceding the European contact saw the demise of Paredão mound villages and their replacement by smaller sites of the polychrome tradition (Figure 3c). Emerging after $\sim A D 700$, rings of house mounds at Paredão sites surround central plazas, showing well-planned village layouts ${ }^{37-39}$. Sites contain thick layers of ADE, and the recovery of phytoliths of maize, yam, squash and Bactris palm, coupled with archaeobotanical evidence of managed forests in the sites' catchment suggest polyculture agroforestry associated with the development of fertile soils ${ }^{40}$ similar to that employed in Santarém. Ultimately, Paredão sites were replaced by smaller, ephemeral settlements with polychrome Guarita ceramics ${ }^{42}$, a pan-Amazonian tradition that originated in the southwestern part of the basin $\sim A D 750^{72}$.

In central Amazon, the appearance of polychrome ceramics coincides with the disintegration of the Paredão complex $\sim A D 1000^{38}$. The homogeneity and rapid spread of polychrome ceramics point to demographic expansions ${ }^{41}$. Alternatively, it is possible that the style was diffused as a prestige technology among groups with access to floodplain resources ${ }^{73}$. What is clear is that the process of transition from Paredão to Guarita polychrome was not a peaceful 
one, as evidenced by defensive ditches and palisades built around Paredão sites, which are later reoccupied by the Guarita tradition ${ }^{41,42}$.

Comparing climate and cultural change in central Amazon is a challenge, given the absence of local palaeoclimatic records and the fact that the region lies in the middle of an eastwest precipitation dipole ${ }^{70}$. As in the case of the Marajoara, the decline of Paredão mound villages coincides with a drier period starting AD 1100 in the Paraíso record ${ }^{19}$ (Figure 3c). However, it is unclear whether a similar change to drier conditions would have manifested in the central Amazon. Palaeoclimate records, including Pumacocha Lake ${ }^{20}$ in the Andes, are recurrently antiphased with the eastern records. These proxies show a period of drought during the MCA period, followed by strengthening of the monsoon during the LIA $22,64,74$. Given the western origin of the polychrome expansion, the MCA drought could have been one of the drivers of the Guarita incursions towards eastern Amazon, ultimately leading to the Paredão collapse.

Southwestern Amazon. Starting $\sim 400$ BC, southwestern Amazon was transformed into a dense ceremonial landscape with geometric enclosures known as geoglyphs ${ }^{43,45,46}$. Over 500 geoglyphs have been recorded. They combine square and circular ditches surrounding areas of 1-3 ha with walled enclosures, avenues and other earthworks. The low ceramic density, presence of votive deposits, and lack of occupation debris suggests geoglyphs were public spaces used for repeated gatherings, rather than permanent settlements ${ }^{30,44,45}$. In spite of the grandeur of the earthworks, there is no evidence of large-scale clearance beyond their immediate vicinity ${ }^{46}$. Nothing is known about the domestic sites of the geoglyph builders, but the absence of size-hierarchies and relative spatial regularity of the geoglyphs suggests dispersed populations ${ }^{30,43,75}$. Phytolith evidence from the ceremonial centres points to the consumption of maize and squash combined with the management of palms ${ }^{46}$. The formative ceremonial network of the southwestern Amazon was dissolved $\sim A D 1000$ and replaced by a new architectural tradition with smaller mound villages, sometimes built on top of or adjacent to earlier geoglyphs (Figure 3d). Discontinuity is also visible in the ceramics recovered from mound villages, which differ markedly from those of the earlier earthworks ${ }^{76}$. Carbonised macro-botanical remains from mound habitation strata include Brazil nuts, palm seeds (Attalea and Euterpe) and maize kernels, suggesting the persistence of polycrop cultivation ${ }^{47}$.

The termination of geoglyph construction coincides with an increase in $\delta^{18} \mathrm{O}$ values observed during the MCA period at Pumacocha Lake, indicating a weakening of the monsoon and decrease of precipitation over the Andes and western Amazon20,77 (Figure 3d). Other palaeoclimate records from the Andean slopes/western Amazonia show precipitation minima at $\sim A D 940$ and 1025 20,77,78. Any causal relationship between drought and the cessation of construction of ceremonial enclosures must remain tentative, given that the settlement patterns of the geoglyph-builders are poorly understood, but the temporal coincidence between the two events is remarkable. Variability in the RCC from southwestern Amazon is not always synchronous with changes in precipitation, showing increase in regional burning after the driest period of the MCA ( AD 900 to 1100; Figure 3d), but coinciding with the earliest dates for the mound villages. Anthropogenic ignitions during the transition from geoglyphs to mound villages following the MCA may have been associated with increased land clearance for the construction of new sites. However, site construction and regional burning are inversely correlated as conditions get progressively wetter during the LIA, suggesting that either climate was the first 
order control for regional fire activity or that burning for land clearance was only practised during the initial establishment of mound villages in the region - perhaps taking advantage of a sparsely inhabited landscape due to the decline of the geoglyph builders.

A strengthening of the monsoon is documented in the Pumacocha record over the following centuries ${ }^{20,77}$, coinciding with the development of mound ring villages. Ceramics from the latter differ from the ceramics of the geoglyphs. The situation of Southwestern Amazon could be similar to that of the Guianas, Central Amazon and Eastern Amazon in that waves of migrants may have been a factor contributing to the decline of local cultures during events of climate change.

Llanos de Moxos. The flooded savanna-forest mosaics of the Llanos de Moxos extend over $150,000 \mathrm{~km}^{2}$ and are one of the most intensely modified landscapes in Amazonia ${ }^{79}$. Different regions of the Llanos de Moxos experienced cultural transformations at the eve of the European contact, from the abandonment of large habitation mounds in the south to the emergence of fortified settlements in the northern part of the Moxos (Figure 3e).

\section{Monumental Mound Region}

The monumental mound region, located in the surroundings of the modern city of Trinidad, Bolivia, is characterised by habitation mounds or lomas up to $21 \mathrm{~m}$ high and 20 ha in surface ${ }^{48}$. Such sites started to be built AD 400 and are part of a network of enclosures, causeways that connect settlements and reservoirs, and drainage and irrigation canals ${ }^{48,51,52}$. Agricultural raised fields, ubiquitous elsewhere in the Llanos de Moxos, are absent, which has been attributed to the relatively good natural drainage in this region ${ }^{49,50}$. Mounds were built on a sedimentary lobe with higher elevation, better drainage and more fertile soils. The canals, some with several $\mathrm{km}$ extension, were built for multiple purposes. Some connect areas with differences in elevation, suggesting drainage as the main function, whereas others divert water from lakes to the surroundings of mounds, presumably for irrigation ${ }^{80}$. Cultivation of maize, manioc, yam, squash, peanuts and cotton has been evidenced by phytoliths, fossil pollen grains and macro-botanical remains $^{53,54}$. Beyond the construction of canals for drainage of cultivated areas ${ }^{49}$, pre-Columbian land use in the monumental mound region also involved more extensive burning of the savannas than was practised in historical times ${ }^{53}$. Funerary evidence points to a highly stratified society, with lavish burial goods reserved for few individuals ${ }^{51,52}$. A hierarchical organisation of sites has also been noticed ${ }^{48}$. Importantly, the extension of some canals suggest their role as public infrastructure built under supra-regional political organisation ${ }^{80}$. The abandonment of this system AD 1400 precedes contact with Europeans and is accompanied by changes in land use with the decline of savanna burning ${ }^{53}$.

\section{Ring Ditch Region}

Around AD 1200, settlements surrounded by ditches known as zanjas began to emerge in the northern portion of the Llanos de Moxos, near modern-day Iténez and Baures, Bolivia. The zanjas exhibit irregular layouts and clear evidence of habitation, including house floors, domestic debris, and urn burials ${ }^{52,55-57}$. Canals and other earthworks connect different enclosures ${ }^{52,57}$. There is no evidence of a regional hierarchy of sites comparable to that of the lomas. Phytolith and pollen evidence show that maize was cultivated and burning was practised to maintain an open 
savanna around the sites during a period of forest expansion ${ }^{56}$. Zanjas are likely the archaeological correlates of fortified settlements described in historical times, attributed by the early chroniclers to increased warfare provoked by incursions from the Guarayos, a Tupi-Guaranispeaking group ${ }^{58}$.

Climate change in the Llanos de Moxos can be inferred from the UmajalantaChiflonkhakha speleothem records from Torotoro Park, tropical slopes of the eastern Andes ${ }^{21}$ (Figure 3e). Changes in precipitation are antiphased with those observed further north ${ }^{21}$. The depleted $\delta^{18} \mathrm{O}$ values during the MCA show an anomalous wet period when compared to other records influenced by the SASM ${ }^{21}$. The following period, marked by a shift to drier conditions, coincides with an increase in fire activity in the RCC (Figure 3e). However, the latter could also be explained by forest clearance ${ }^{56}$. Previous studies have argued that pre-Columbian fire management in the zanjas was used to clear agricultural lands from encroaching forests in response to the orbitally-driven southward migration of the rainforest ecotone ${ }^{81}$. Importantly, the RCCs for both southwestern Amazon and the Llanos de Moxos suggest human activity as the main driver of recent biomass burning, supporting the hypothesis that late Holocene fires in this region were anthropogenic ${ }^{82}$.

The abandonment of the lomas took place in the centuries between the MCA and the LIA, during which time conditions of prolonged drought reached their peak $\sim A D$ 1300-1500. This is in agreement with a trend of increased aridity recorded in Lake Titicaca's water levels ${ }^{83}$ and documented in the Quelccaya ice cap ${ }^{84}$, possibly linked to the collapse of the Tiwanaku state ${ }^{8,9,85}$. We argue that the same effects were felt in the Llanos de Moxos. In the monumental mound region, earthworks such as canals were possibly more important in the mitigation of seasonal floods than for irrigation ${ }^{80}$, suggesting that those societies might have been more resilient to conditions of increased precipitation than to droughts. Unlike the previous case studies, the abandonment of the sites does not seem to have been followed or caused by the arrival of foreigners, reinforcing the role of climate change. However, concomitant with the demise of the lomas, and potentially related to their abandonment, settlements further north began to be enclosed by defensive ditches, signalling the intensification of warfare ${ }^{86}$.

Southern Amazon. The transitional forests of southern Amazon were densely settled with enclosed sites and other earthworks, as exemplified by the network of fortifications and roads in the upper Xingu (Xinguano Tradition).

After AD 1100, settlements in this region were remodelled with the addition of ditches, walled plazas and causeways (Figure 3f). Large, complex settlements constitute the hubs of a network of roads extending for $\sim 20,000 \mathrm{~km}^{2}$ that connect them to smaller villages, reflecting independent regional polities ${ }^{59-61}$. The largest sites, over 20 ha, contain extensive ADE, occupation debris, house floors and middens, and are estimated to have had a population over $2500^{61}$. The Xinguano system was probably heterarchical, revolving around political-ceremonial centres. Ditched enclosures associated with ADE in the Tapajós headwaters, further to the west, demonstrate spatial continuity from the upper Xingu to the Bolivian zanjas ${ }^{87}$. Together, these data indicate that the development of fortified sites must be understood as a large-scale phenomenon characterising the southern Amazon. 
The $\delta^{18} \mathrm{O}$ record from the Pau d'Alho cave speleothem documents oscillations in the intensity of the SASM in western and central Brazil for the past 1500 years ${ }^{22}$ (Figure $3 f$ ). Trends observed at Pau d'Alho are reflected elsewhere in central Brazil and are related to shifts in the mean position of the South Atlantic Convergence Zone (SACZ) ${ }^{62}$. Regions under significant influence of the SACZ do not show the same departures from the mean state of the monsoon during the MCA and LIA as western Amazonia or eastern Brazil, but rather a strong multi-decadal to centennial-scale variability in the transition between those two periods ${ }^{22,62,88}$. It was during this period of increased climatic volatility that settlements in the upper Xingu were fortified. Enclosures emerged elsewhere under different conditions. In the Llanos de Moxos, zanjas appeared during an episode of drought, suggesting a climatic driver. Overall, defensive structures must be understood in a broader context of warfare in Amazonia, whether or not related to climate change. 


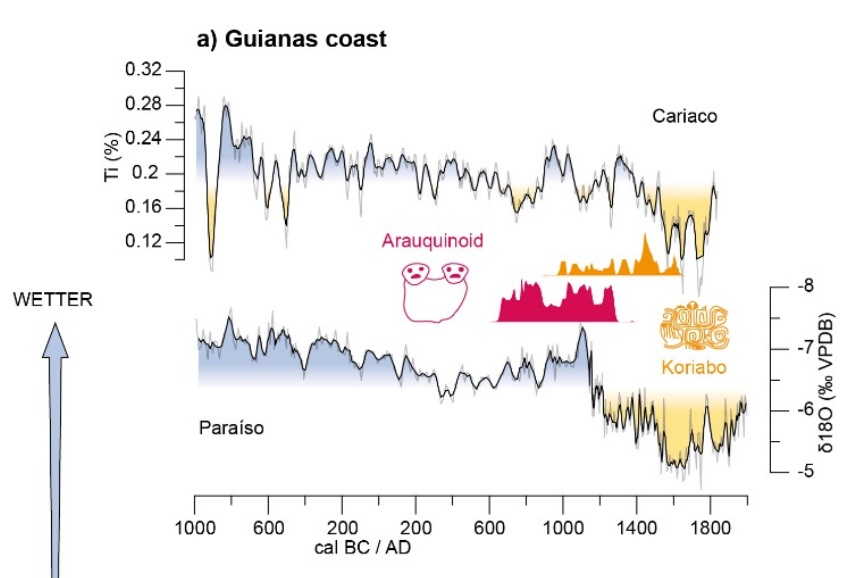

c) Central Amazon

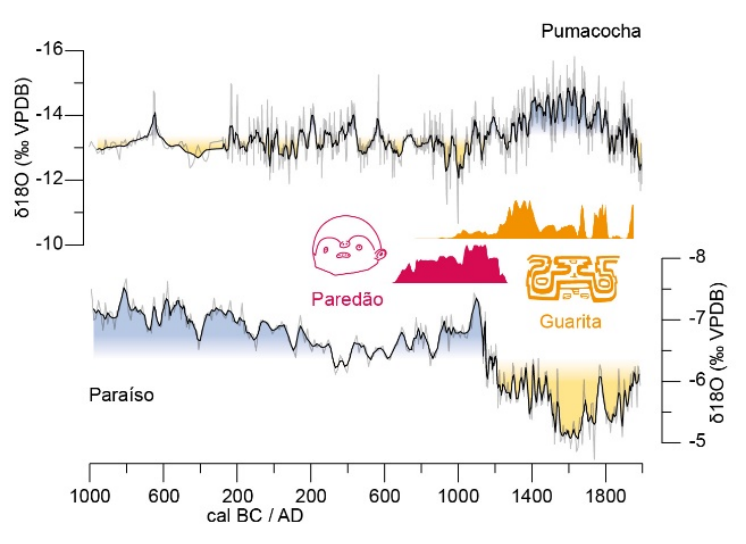

e) Llanos de Moxos

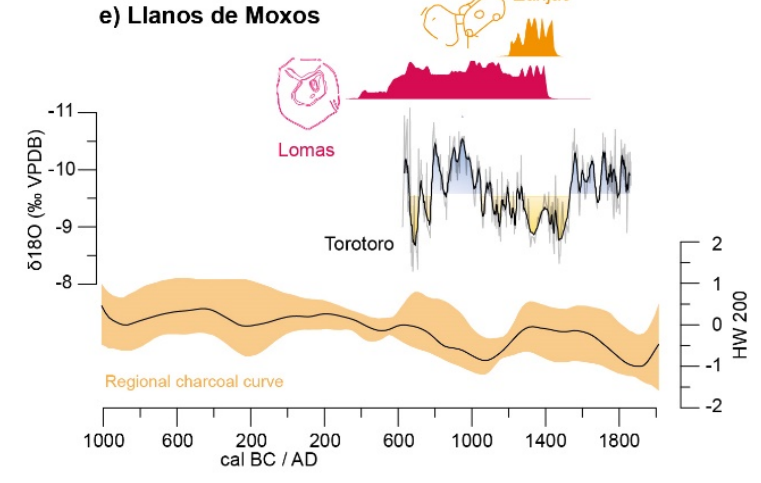

b) Eastern Amazon

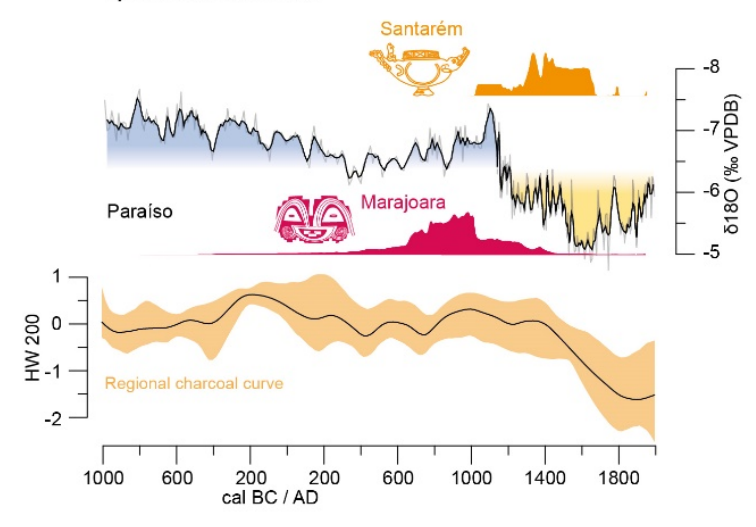

d) Southwestern Amazon

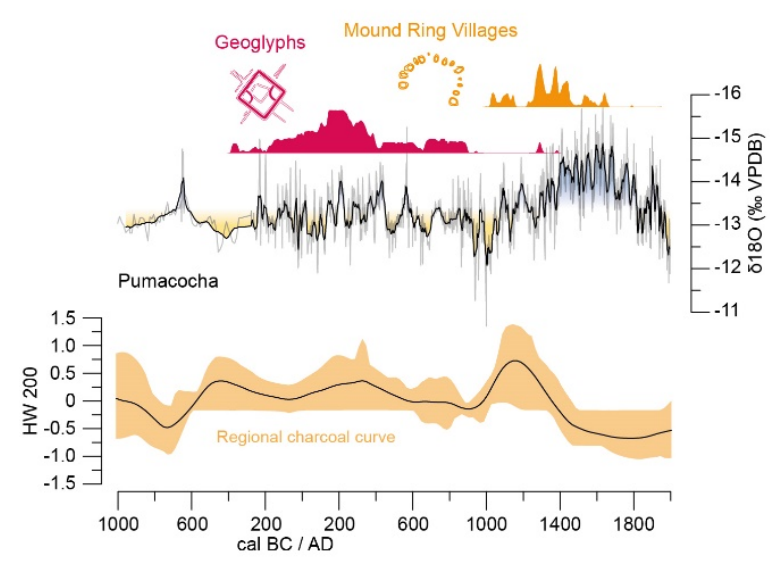

f) Southern Amazon

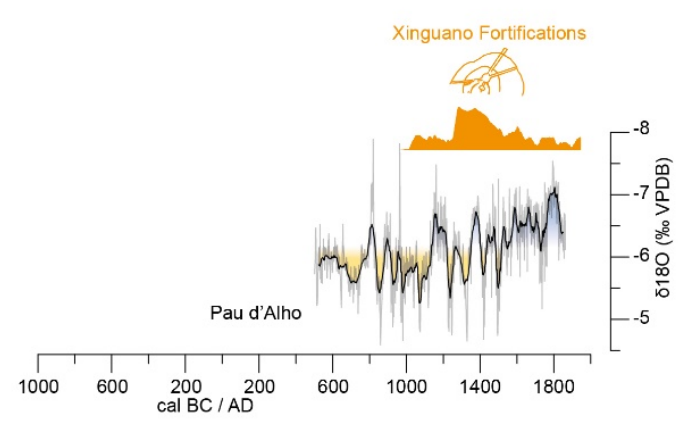

Figure 3. Periods of cultural change and palaeoclimate records for six regions of Greater Amazonia, and regional charcoal curves from the best sampled regions (Supplementary Methods). The duration of each archaeological culture is represented by summed calibrated probability distributions (SPDs) of the radiocarbon dates (magenta and orange lines) (Supplementary Tables 1-6, Supplementary Note, Supplementary Methods). The "wetter" and "drier" arrows refer to the interpretation of the palaeoprecipitation records. For location of each region and palaeoclimate record, see Figure 1. For location of charcoal records, see Supplementary Table 7 and Supplementary Figure 1.

\section{Discussion}


Previous attempts to relate climate and culture in Amazonia postulated a deterministic link between environment and society ${ }^{89}$. The view that the environment imposed limitations to development in the tropics has been refuted by archaeological evidence of dense populations and complex societies in Amazonia, starting in the $1960 \mathrm{~s}^{90}$ and continuing today ${ }^{3,87}$. Due to this paradigm shift, correlations between climate change and cultural transformations were not thoroughly explored, as the topic may be perceived to evoke outdated views. Here, we have identified temporal synchronicities between climate and cultural change in Amazonia. Elsewhere in the Americas, periods of abrupt change in the archaeological record have been shown to coincide with climatic events ${ }^{91,92}$. In Amazonia, however, the causality of these cultural changes is more difficult to ascertain. While some cultures were flourishing at the eve of the European encounter, sustaining dense populations and large settlements (e.g. lower Tapajós), other societies with intensive landscape management systems, elaborate material culture and status inequalities had long disappeared and been replaced by smaller, mobile groups (e.g. Marajó Island). There is growing evidence that the millennium preceding the European encounter was a period of transformations, with long-distance migrations, conflict, disintegration of complex societies and social reorganisation across lowland South America ${ }^{30,42,93}$.

\section{Two models of land use}

When differences in social organisation and land-use are taken into account, a pattern emerges (Figure 4). Most of the pre-Columbian societies reviewed in this paper developed economic strategies that can be encompassed under the concept of 'landesque capital', which entails investment in infrastructure and landscape modifications that provide increased yields not only for the duration of one's lifespan, but also for future generations ${ }^{94}$. The construction of raised fields ${ }^{95,96}$, the formation of $\mathrm{ADEs}^{40}$, forest enrichment ${ }^{16,36,97}$, and the creation of artificial ponds for management of aquatic resources ${ }^{29}$, are all examples of landesque investment. Nevertheless, these are very distinct strategies, and it is unlikely that all of them would have been vulnerable to the same climatic fluctuations.

Here, we suggest that pre-Columbian societies with more intensive and specialised land use systems were more vulnerable to transient (short-term but highly variable) events of climate change during the late Holocene. These societies also tended to exhibit greater social stratification and settlement hierarchies, as is clear from the examples of Marajó Island and the monumental mound region in the Llanos de Moxos, in conformity with the cross-cultural observation that intensification coevolves with complex political structures ${ }^{98-100}$. The presence of status inequality and centralised decision-making may be key for understanding why those communities disappeared during periods of climate change whereas other societies were unaffected. Political complexity may lead to rapid growth in the short term but also to increased vulnerability in the long term due to high interdependency of the constituent parts of the social system, so that changes in any component are likely to compromise the system as a whole and cause general collapse ${ }^{101-103}$. Furthermore, complex societies tend to promote and depend on the production of constant yields and surplus through intensification and specialisation in resource exploitation, losing their ability to absorb unforeseen disturbances ${ }^{12,13,104-106}$. For example, economies depending on earthworks that changed hydrology, as in the case of drainageenhancing canals found in the Llanos de Moxos, may become unstable during periods of drought. 
Vulnerability is further influenced by the environment in which the later (as well as the Marajoara chiefdoms) developed, since flooded ecosystems are prone to fire and erosion during drought ${ }^{107}$.

We argue that Amazonian societies featuring high population densities, settlement hierarchy, ruling elites, and intensive land-use systems (e.g. the monumental mounds in the Llanos de Moxos, Marajoara in the eastern Amazon, and Arauquinoid in the Guianas coast) became vulnerable to external factors, such as climate change. This is well illustrated by the decline of the monumental mound region during the dry period $\sim A D$ 1300-1500, at the peak of regional political complexity and settlement density. The same societies were unaffected by a more severe drought $\sim$ AD 700 (Figure 3e) when they were at the initial phases of their adaptive cycle (see below).

Alternatively, other pre-Columbian societies were experiencing a momentum of growth at the eve of the European encounter, as exemplified in the lower Tapajós and southern Amazonia. These regions had high population densities and large settlements spread over considerable areas. However, there is little evidence of political hierarchy. The Xinguano system in southern Amazonia has been described as a 'galactic' system with multiple political-ritual centres in a decentralised organisation ${ }^{59-61}$.

The Santarém culture is an ambiguous case. Historical accounts describe a tribute-based chiefdom in the lower Tapajós ${ }^{31,32}$ whose capital could be the large settlement under the modern city of Santarém ${ }^{31}$. However, no archaeological evidence was found of differential access to prestige goods, high-status burials, or conflict ${ }^{34}$. The cultural affiliation of sites at the periphery of the Santarém sphere of influence shed doubt on the territorial extent of the polity ${ }^{35,108}$. Recent reviews of the archaeology of the lower Tapajós propose heterarchical models of political organization, either with a centralised organisation encompassing independent communities ${ }^{35}$ or a non-centralised polity based on a regional collaborative network ${ }^{34,109}$. As for the Guarita of Central Amazon, Koriabo of the Guianas coast or mound villages of southwestern Amazon, there is little to no evidence of regional site hierarchies or social stratification.

Beyond their decentralised political structures, the unifying factor in these societies' perseverance may have been their land-use systems. Although archaeobotanical data are still scarce for many of the case studies listed above, Amazonian cultures like Santarém are known to have combined (i) the exploitation of ADEs and (ii) the enrichment of forests with plants of economic importance ${ }^{36}$. ADEs, estimated to cover up to $3.2 \%$ of the Amazon Basin, have received considerable attention due to their persistent fertility, constituting a crucial resource for sustainable agricultural practices in modern-day Amazonia110-112. The mechanism behind the formation of ADEs have been widely debated, with ethnographic analogues and experiments suggesting the resilient fertility results from the long term repeated incorporation of waste material and charred biomass ${ }^{113-115}$. Forests with hyperdominant edible and useful species are significantly associated with ADE sites throughout Amazonia, which has been interpreted as an imprint of preColumbian land use ${ }^{16,116,117}$. Confirmation is provided by fossil pollen evidence, showing that modern floristic composition in ADE sites results from millennia of forest enrichment associated with prolonged human settlement, but in the absence of large-scale deforestation ${ }^{36}$. The creation of 'domesticated forests' through selection, transportation and encouragement of useful species, often associated with improved soils, ensured permanently enriched environments and food security in the long term ${ }^{16,97}$. 
The present-day prevalence of clearance for slash-and-burn agriculture in Amazonia has been suggested to result from the availability of metal tools, with more intensive management of gardens and forests in different stages of succession being the pattern in pre-Columbian times ${ }^{37}$. Nevertheless, clearance and burning do seem to have played a role in the establishment of ADEs, with later fire management suppressing larger wildfires ${ }^{36}$. Furthermore, it is possible that an infield-outfield system, similar to that of Mesoamerica, combining polyculture gardens with less labour-intensive swidden further from the settlements, also existed in Amazonia ${ }^{118}$. In line with previous arguments about the sustainability of polyculture agroforestry in the Neotropics ${ }^{36}$, our review of the archaeological and palaeoclimate record suggests that these land-use systems provided pre-Columbian Amazonian societies with resilience to both transient and protracted (multi-year to multi-decade) climate variability when compared to specialised production maximisation strategies.
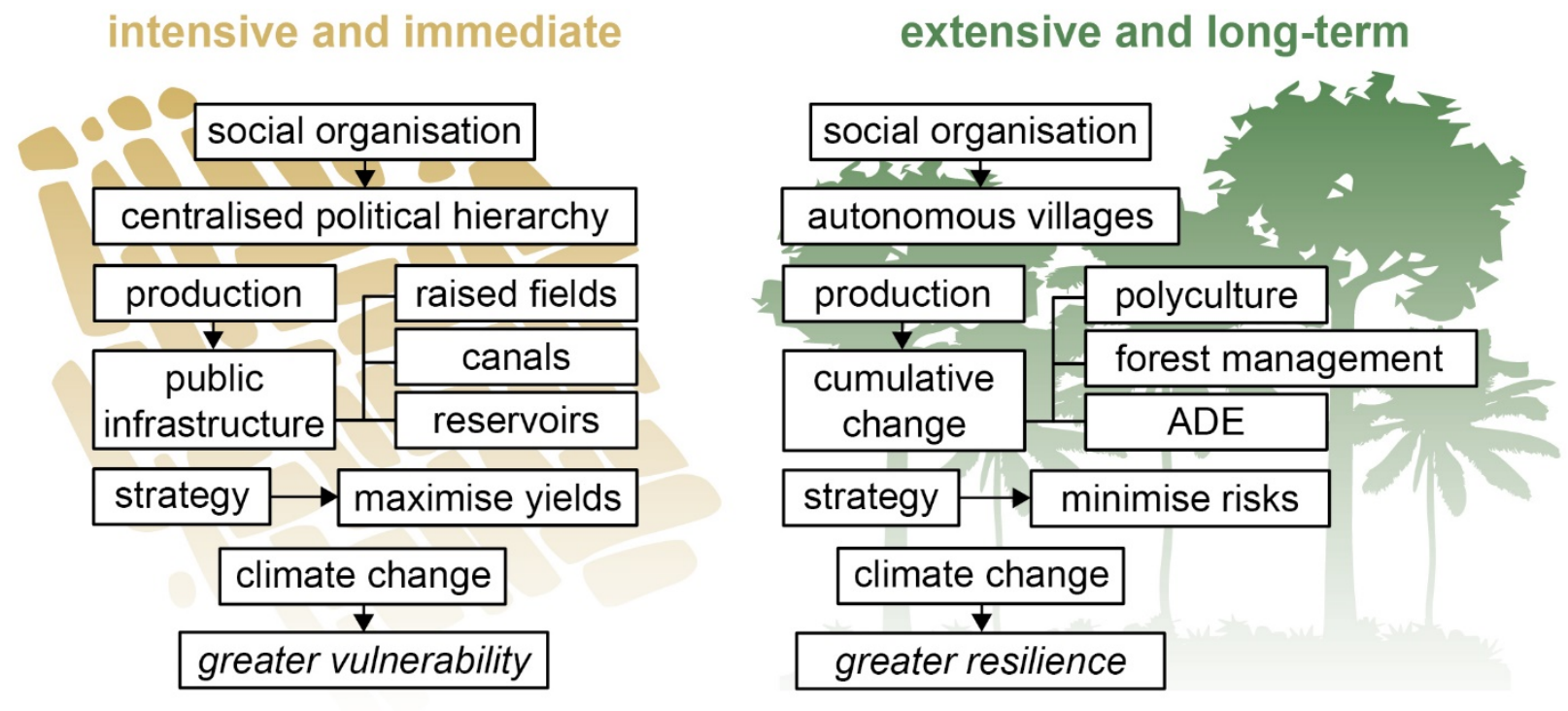

Figure 4. Two models of land use in late pre-Columbian Amazonia. Not all the characteristics listed in each panel are present simultaneously in one society, e.g. some may exhibit centralised political hierarchy but rely on polyculture agroforestry, while others may be decentralised but invest labour in raised fields and other earthworks. Nevertheless, late pre-Columbian Amazonian cultures tend to resemble more closely one or another of these ideal types.

\section{Risk management and adaptive cycles}

The patterns summarised above are in agreement with the body of theory on risk management strategies and are comparable to other cases where different land use strategies have triggered opposing responses in the face of environmental change. Populations residing in stable environments have been suggested to benefit, in the short term, from maximisation strategies, which provide high yields and surplus that can be diverted to the maintenance of political complexity and large populations. However, they were also found to suffer heavier losses in events of environmental perturbation. In contrast, populations practising risk minimisation strategies (population control, mobility, diversification) are considered to be more stable in 
unpredictable environments over the long term ${ }^{11}$. In that regard, the economic and social disparities between the various regions of Amazonia resemble the Polynesian cases of Mangaia and Tikopia ${ }^{10}$. Mangaia was covered by old growth forest depending on thin organic soils that were soon depleted by the slash-and-burn agriculture of the initial colonists. Soil depletion resulted in the eventual need to develop irrigation systems on valley bottoms, leading to strong leadership and competitive warfare. In contrast, Tikopia offered a more resilient environment, but the determining factor in its success was the shift from slash-and-burn agriculture to a form of arboriculture that mimicked the diversity of the rainforest ${ }^{10}$.

Beyond risk management, panarchy theory, through the concept of adaptive cycles, helps understanding the patterns of growth and decline of late pre-Columbian Amazonian societies. Panarchy theory was devised to explain the dynamics of social-ecological systems, postulating the existence of interlinked adaptive cycles, observed at multiple independent spatial scales. The cycles involve stages of growth/exploitation ( $r)$, conservation/construction $(k)$, release $(\Omega)$ and, ultimately, reorganisation $(\alpha)^{12-14}$. The first two phases comprise a long period during which resources are accumulated, whereas the latter two phases develop over a short period of sudden energy release. In human societies, reorganisation often involves rescaling of population towards smaller communities, only to begin a new cycle. Regionally-integrated, hierarchical societies, however, tend to resist such fluctuations and artificially prolong the growth and conservation stages. By attempting to maintain constant yields through economic intensification, specialisation, and political centralisation, these societies accumulate rigidities. They may appear sustainable while, in fact, developing lower resilience and becoming prone to crisis under the stress of external agents, such as climate hazards ${ }^{14}$. We argue that archaeological cultures including those of the monumental mound region in the Llanos de Moxos, Marajó Island, and Guianas coast, with their high population densities, hierarchy of settlements, ruling elite, and intensive land use systems, were approaching the $\Omega$ phase and had become more vulnerable to climate change, causing their overall collapse and reorganisation.

Finally, we highlight that the different intentionality and social organisation behind the landuse systems, as discussed above, may have bearings on their resilience. The construction of raised fields, artificial ponds, canals and other earthworks are voluntary practices of terraforming with the immediate aim of intensifying production. In Amazonia as elsewhere, their construction both sustained and depended on complex political organisations ${ }^{98}$. Yet, productive earthworks were not reutilised after the European conquest. Despite improving agricultural potential in the short term, the raised fields of the Llanos de Moxos developed worse soil properties than the surrounding savannas due to leaching ${ }^{49}$. Rehabilitation of raised field agriculture has also failed due to social factors, reinforcing its dependence on a particular form of political organisation ${ }^{119}$. In contrast, anthropogenic forests and ADEs continue to be exploited by local Amazonian communities, even though the actions that resulted in their formation, such as species selection and midden disposal, were art of broader strategies and not consciously intended for immediate advantage ${ }^{97,120}$. Crucially, anthropogenic forests with enriched flora and fertile soils were of benefit regardless of social organisation, one of the reasons behind their resilience.

\section{Other drivers of change: migration and conflict}

Obvious exceptions to the above are the cases of central and southwestern Amazon. In southwestern Amazon, little is known about the domestic sites of the geoglyph-builders, but they 
were most likely small-scale communities practising crop cultivation and forest enrichment ${ }^{46}$. No evidence has been found of $A D E s^{111}$, which reinforces the observation that, elsewhere, anthropogenic soil formation was the key to provide a successful and resilient form of agricultural production in the Neotropics ${ }^{36,111,121,122}$.

In central Amazon, climate change may be less relevant to explain the demise of the Paredão mound villages, which also practised polyculture agroforestry and ADE formation, than conflict provoked by incursions of the Guarita groups ${ }^{41,42}$. Migrations have also been invoked in the case of Marajó and the Guianas coast. Population displacements were a phenomenon documented throughout Amazonia during late pre-Columbian times ${ }^{41}$. Rather than suggesting climate change as the only cause for all transformations reviewed in this paper, we recognise the turn of the second millennium $A D$ as a period of widespread reorganisation and population movement, among which climate change may have played a role. A similar scenario is exemplified by the "crisis" of the Late Bronze Age ( 1200-1150 BC), when prolonged droughts set in motion migrations, warfare and upheavals throughout the Eastern Mediterranean, leading to the dissolution of once powerful polities ${ }^{123-125}$. Societies otherwise unaffected by climate change could have faced challenges as part of a chain reaction set in motion by broader population relocations across South America - as in the case of the purported 'ripple effects' of the Tiwanaku collapse ${ }^{126}$.

\section{Conclusion}

Considerable population declines followed the European encounter (AD 1492) in the Americas, but population dynamics preceding that date remain underexplored. While major cultural demises in the US Southwest, Mesoamerica and the Andes have taken place in response to climate change before the European arrival, similar changes in Amazonia remain poorly understood. By comparing archaeological data with palaeoclimate proxies and regional-scale burning, we show that some Amazonian cultures flourished during periods of climate change, whereas others collapsed. We argue that differences in land-use and socio-political organisation may be key to understanding vulnerability versus resilience to environmental stress.

Recent debates about the post-AD 1492 population collapse in the Americas have focused on consequences for forest regrowth, decrease of atmospheric $\mathrm{CO}_{2}$ and exacerbation of climate change and impacts on biodiversity that occurred during the LIA 2,127-129. As more archaeological, palaeoclimatological, and palaeoecological data become available and integrated, we foresee a refinement of our understanding about land-use and population densities across the neotropics. By continuing to explore how different cultures responded to climate change, and documenting transformations prior to AD 1492, we expect major contributions will be made to understand the demographic and environmental consequences of the Columbian encounter.

\section{Correspondence}

Correspondence should be addressed to J.G.S. (jonas.gregorio@gmail.com).

\section{Author contributions}


J.I., J.G.S. and M.R. designed the research. J.G.S., M.R., J.C., J.A.H., U.L., D.T.A., S.R. and J.I. compiled and interpreted archaeological data. V.F.N., J.A. and F.W.C. compiled and interpreted palaeoclimatic data. S.Y.M. and M.J.P. compiled and interpreted palaeofire data. B.W., D.U., F.E.M. and H.H. compiled and interpreted palaeoecological data. J.G.S. led the writing of the paper with inputs from all other authors.

\section{Acknowledgements}

This paper is the result of the 2016 international workshop "Land use and climate changes at the eve of conquest: an interdisciplinary approach", part of the PAST project funded by the European Research Council (ERC) under the European Union's Horizon 2020 research and innovation programme (grant agreement No. ERC_Cog 616179). F.W.C. was supported by a São Paulo Research Foundation (FAPESP) grant: 2017/50085-3. V.F.N. was supported by a São Paulo Research Foundation (FAPESP) grant: 2016/15807-5. We thank the members of the PAGES sponsored Global Paleofire Working Group for their support for the global charcoal database.

\section{References}

1 Dobyns, H. F. An Appraisal of Techniques with a New Hemispheric Estimate. Current Anthropology 7, 395-416 (1966).

2 Koch, A., Brierley, C., Maslin, M. M. \& Lewis, S. L. Earth system impacts of the European arrival and Great Dying in the Americas after 1492. Quaternary Science Reviews 207, 13-36, doi:https://doi.org/10.1016/j.quascirev.2018.12.004 (2019).

3 Clement, C. R. et al. The domestication of Amazonia before European conquest. Proceedings of the Royal Society B: Biological Sciences 282, 20150813 (2015).

4 Denevan, W. M. Estimating Amazonian Indian Numbers in 1492. Journal of Latin American Geography 13, 207-221 (2014).

5 Polyak, V. J. \& Asmerom, Y. Late Holocene climate and cultural changes in the southwestern United States. Science 294, 148-151, doi:10.1126/science.1062771 (2001).

6 Kennett, D. J. et al. Development and Disintegration of Maya Political Systems in Response to Climate Change. Science 338, 788-791 (2012).

7 Douglas, P. M. J., Demarest, A. A., Brenner, M. \& Canuto, M. A. Impacts of Climate Change on the Collapse of Lowland Maya Civilization. Annual Review of Earth and Planetary Sciences 44, 613-645, doi:10.1146/annurev-earth-060115-012512 (2016).

8 Ortloff, C. R. \& Kolata, A. L. Climate and Collapse: Agro-Ecological Perspectives on the Decline of the Tiwanaku State. Journal of Archaeological Science 20, 195-221, doi:https://doi.org/10.1006/jasc.1993.1014 (1993).

9 Binford, M. W. et al. Climate Variation and the Rise and Fall of an Andean Civilization. Quaternary Research 47, 235-248, doi:https://doi.org/10.1006/qres.1997.1882 (1997).

10 Kirch, P. V. Microcosmic Histories: Island Perspectives on "Global" Change. American Anthropologist 99, 30-42 (1997).

11 Allen, M. S. Bet-hedging strategies, agricultural change, and unpredictable environments: historical development of dryland agriculture in Kona, Hawaii. Journal of Anthropological Archaeology 23, 196-224, doi:https://doi.org/10.1016/j.jaa.2004.02.001 (2004). 
12 Gunderson, L. H. \& Holling, C. S. (Island Press, Washington, D.C., 2002).

13 Holling, C. S. in Sustainable development of the biosphere (eds W.C. Clark \& R.E. Munn) 292-317 (Cambridge University Press, 1986).

14 Holling, C. S. Understanding the Complexity of Economic, Ecological, and Social Systems. Ecosystems 4, 390-405, doi:10.1007/s10021-001-0101-5 (2001).

15 WinklerPrins, A. Locating Amazonian Dark Earths: Creating an interactive GIS of known locations. Journal of Latin American Geography 9, 33-50 (2010).

16 Levis, C. et al. Persistent effects of pre-Columbian plant domestication on Amazonian forest composition. Science 355, 925-931, doi:10.1126/science.aal0157 (2017).

17 IPHAN. National Register of Archaeological Sites (CNSA), 2018).

18 Haug, G. H., Hughen, K. A., Sigman, D. M., Peterson, L. C. \& Rohl, U. Southward migration of the intertropical convergence zone through the Holocene. Science 293, 1304-1308 (2001).

19 Wang, X. et al. Hydroclimate changes across the Amazon lowlands over the past 45,000 years. Nature 541, 204 (2017).

20 Bird, B. W. et al. A 2,300-year-long annually resolved record of the South American summer monsoon from the Peruvian Andes. Proceedings of the National Academy of Sciences 108, 8583-8588 (2011).

21 Apaéstegui, J. et al. Precipitation changes over the eastern Bolivian Andes inferred from speleothem $(\delta 180)$ records for the last 1400 years. Earth and Planetary Science Letters 494, 124-134, doi:https://doi.org/10.1016/j.epsl.2018.04.048 (2018).

22 Novello, V. F. et al. Centennial-scale solar forcing of the South American Monsoon System recorded in stalagmites. Sci Rep-Uk 6 (2016).

23 Rostain, S. Islands in the rainforest: landscape management in pre-Columbian Amazonia. (Left Coast, 2013).

24 Versteeg, A. H. in Handbook of South American Archaeology (eds Helaine Silverman \& William H. Isbell) 303-318 (Springer, 2008).

25 Iriarte, J. et al. Late Holocene Neotropical agricultural landscapes: phytolith and stable carbon isotope analysis of raised fields from French Guianan coastal savannahs. Journal of Archaeological Science 37, 2984-2994, doi:https://doi.org/10.1016/j.jas.2010.06.016 (2010).

26 McKey, D. et al. Pre-Columbian Agricultural Landscapes, Ecosystem Engineers and Self-organized Patchiness in Amazonia. Proceedings of the National Academy of Sciences 107, 7823-7828 (2010).

27 Van den Bel, M. in Arqueologia Amazônica (eds E. Pereira \& V. Guapindaia) 61-93 (Museu Paraense Emilio Goeldi, 2010).

28 Roosevelt, A. C. Moundbuilders of the Amazon: geophysical archaeology on Marajo Island, Brazil. (Academic Press, 1991).

29 Schaan, D. P. The Camutins Chiefdom: Rise and Development of Social Complexity on Marajó Island, Brazilian Amazon, University of Pittsburgh, (2004).

30 Schaan, D. P. Sacred Geographies of Ancient Amazonia: Historical Ecology of Social Complexity. (Left Coast Press, 2011).

31 Roosevelt, A. C. in Complex Polities in the Ancient Tropical World (eds Elisabeth A. Bacus \& Lisa J. Lucero) 13-33 (Archaeological Papers of the American Anthropological Association, 1999).

32 Nimuendajú, C. Os Tapajó. Boletim do Museu Paraense Emílio Goeldi 10, 93-106 (1948).

33 Gomes, D. M. C. The diversity of social forms in pre-colonial Amazonia. Revista de Arqueología Americana, 189-225 (2007).

34 Schaan, D. P. in Beyond Waters: Archaeology and environmental history of the Amazonian Inland (ed P. D. Stenborg) 23-36 (University of Gothenburg, 2016). 
35 Gomes, D. M. C. Politics and Ritual in Large Villages in Santarém, Lower Amazon, Brazil. Cambridge Archaeological Journal 27, 275-293, doi:10.1017/S0959774316000627 (2016).

36 Maezumi, S. Y. et al. The legacy of 4,500 years of polyculture agroforestry in the eastern Amazon. Nature Plants 4, 540-547 (2018).

37 Neves, E. G. in Human-Environment Interactions: Current and Future Directions (eds Eduardo S. Brondízio \& Emilio F. Moran) 371-388 (Springer Netherlands, 2013).

38 Neves, E. G. \& Petersen, J. B. in Time and complexity in historical ecology: studies in the neotropical lowlands (eds William Balée \& Clark L. Erickson) 279-310 (Columbia University Press, 2006).

39 Heckenberger, M. J., Petersen, J. B. \& Neves, E. G. Village size and permanence in Amazonia: two archaeological examples from Brazil. Latin American Antiquity 10, 353376 (1999).

40 Bozarth, S. R., Price, K., Woods, W. I., Neves, E. G. \& Rebellato, R. in Amazonian Dark Earths: Wim Sombroek's Vision (eds William I. Woods et al.) 85-98 (Springer Netherlands, 2009).

41 Neves, E. in Ethnicity in Ancient Amazonia: Reconstructing Past Identities from Archaeology, Linguistics, and Ethnohistory (eds A. Hornborg \& J.D. Hill) 31-56 (University of Colorado Press, 2011).

42 Moraes, C. d. P. \& Neves, E. G. O ano 1000: adensamento populacional, interação e conflito na Amazônia Central. Amazônica-Revista de Antropologia 4, 122-148 (2012).

43 Pärssinen, M., Schaan, D. P. \& Ranzi, A. Pre-Columbian geometric earthworks in the upper Purús: a complex society in western Amazonia. Antiquity 83, 1084-1095 (2009).

44 Saunaluoma, S. \& Schaan, D. Monumentality in Western Amazonian formative societies: geometric ditched enclosures in the Brazilian state of Acre. Antiqua 2, 1 (2012).

45 Schaan, D. et al. New radiometric dates for precolumbian (2000-700 B.P.) earthworks in western Amazonia, Brazil. Journal of Field Archaeology 37, 132-142 (2012).

46 Watling, J. et al. Impact of pre-Columbian "geoglyph" builders on Amazonian forests. Proceedings of the National Academy of Sciences 114, 1868-1873 (2017).

47 Neves, E. G. et al. Pesquisa e Formação nos Sítios Arqueológicos Espinhara e Sol de Campinas do Acre - PESC. (University of São Paulo, São Paulo, 2016).

48 Lombardo, U. \& Prümers, H. Pre-Columbian human occupation patterns in the eastern plains of the Llanos de Moxos, Bolivian Amazonia. Journal of Archaeological Science 37, 1875-1885 (2010).

49 Lombardo, U., Denier, S., May, J.-H., Rodrigues, L. \& Veit, H. Human-environment interactions in pre-Columbian Amazonia: The case of the Llanos de Moxos, Bolivia. Quaternary International 312, 109-119, doi:https://doi.org/10.1016/j.quaint.2013.01.007 (2013).

50 Lombardo, U., Denier, S. \& Veit, H. Soil properties and pre-Columbian settlement patterns in the Monumental Mounds Region of the Llanos de Moxos, Bolivian Amazon. SOIL 1, 65-81, doi:10.5194/soil-1-65-2015 (2015).

51 Prümers, H. ¿"Charlatanocracia" en Mojos? investigaciones arqueológicas en la Loma Salvatierra, Beni, Bolivia. Boletin de Arqueologia PUCP 11, 103-116 (2007).

52 Prümers, H. \& Jaimes Betancourt, C. 100 años de investigación arqueológica en los Llanos de Mojos. Arqueoantropológicas 4, 11-54 (2014).

53 Whitney, B. S., Dickau, R., Mayle, F. E., Soto, J. D. \& Iriarte, J. Pre-Columbian landscape impact and agriculture in the Monumental Mound region of the Llanos de Moxos, lowland Bolivia. Quaternary Research 80, 207-217, doi:https://doi.org/10.1016/j.yqres.2013.06.005 (2013).

54 Dickau, R. et al. Diversity of cultivars and other plant resources used at habitation sites in the Llanos de Mojos, Beni, Bolivia: evidence from macrobotanical remains, starch 
grains, and phytoliths. Journal of Archaeological Science 39, 357-370, doi:https://doi.org/10.1016/j.jas.2011.09.021 (2012).

55 Prümers, H., Jaimes Betancourt, C. \& Plaza Martinez, R. Algunas tumbas prehispanicas de Bella Vista, Prov. Iténez, Bolivia. Zeitschrift für Archäologie Außereuropäischer Kulturen 1, 251-284 (2006).

56 Carson, J. F. et al. Environmental impact of geometric earthwork construction in preColumbian Amazonia. Proceedings of the National Academy of Sciences 111, 1049710502 (2014).

57 Prümers, H. in Amazonía: Memorias de las Conferencias Magistrales del 3er Encuentro Internacional de Arqueología Amazónica (ed Stéphen Rostain) 73-89 (Ekseption Publicidad, 2014).

58 Erickson, C. L. in Arqueología de las Tierras Bajas (eds Alicia Durán Coirolo \& Roberto Bracco Boksar) 207-226 (Comisión Nacional de Arqueología, 2000).

59 Heckenberger, M. J. et al. Amazonia 1492: Pristine Forest or Cultural Parkland? Science 301, 1710-1714 (2003).

60 Heckenberger, M. J. The ecology of power: culture, place, and personhood in the southern Amazon, A.D. 1000-2000. (Routledge, 2005).

61 Heckenberger, M. J. et al. Pre-Columbian Urbanism, Anthropogenic Landscapes, and the Future of the Amazon. Science 321, 1214-1217 (2008).

62 Novello, V. F. et al. Two Millennia of South Atlantic Convergence Zone Variability Reconstructed From Isotopic Proxies. Geophys Res Lett 0, doi:doi:10.1029/2017GL076838 (2018).

63 Mann, M. E. et al. Global Signatures and Dynamical Origins of the Little Ice Age and Medieval Climate Anomaly. Science 326, 1256-1260, doi:10.1126/science.1177303 (2009).

64 Vuille, M. et al. A review of the South American monsoon history as recorded in stable isotopic proxies over the past two millennia. Climate of the Past 8, 1309 (2012).

65 Hammond, D. S., Steege, H. t. \& Van Der Borg, K. Upland Soil Charcoal in the Wet Tropical Forests of Central Guyana. Biotropica 39, 153-160, doi:doi:10.1111/j.17447429.2006.00257.x (2007).

66 Iriarte, J. et al. Fire-free land use in pre-1492 Amazonian savannas. Proceedings of the National Academy of Sciences 109, 6473-6478 (2012).

67 Schaan, D. P. in The Handbook of South American Archaeology (eds Helaine Silverman \& William H. Isbell) 339-357 (Springer New York, 2008).

68 Hermenegildo, T., O'Connell, T. C., Guapindaia, V. L. C. \& Neves, E. G. New evidence for subsistence strategies of late pre-colonial societies of the mouth of the Amazon based on carbon and nitrogen isotopic data. Quaternary International 448, 139-149, doi:https://doi.org/10.1016/j.quaint.2017.03.003 (2017).

69 Meggers, B. J. \& Evans, C. Archaeological investigations at the mouth of the Amazon. (Smithsonian Institution, 1957).

70 Cheng, H. et al. Climate change patterns in Amazonia and biodiversity. Nature Communications 4, 1411, doi:10.1038/ncomms2415 (2013).

71 Lara, R. J. \& Cohen, M. C. L. Palaeolimnological studies and ancient maps confirm secular climate fluctuations in Amazonia. Climatic Change 94, 399-408 (2009).

72 Almeida, F. O. \& Neves, E. G. in Antes de Orellana: Actas del 3er Encuentro Internacional de Arqueología Amazónica (ed S. Rostain) 175-182 (Ekseption Publicidad, 2014).

73 Oliveira, E. in Cerâmicas arqueológicas da Amazônia: rumo a uma nova síntese (eds Cristiana Barreto, Helena P. Lima, \& Carla J. Betancourt) 387-396 (IPHAN/Ministério da Cultura, 2012). 
74 Novello, V. F. et al. Multidecadal climate variability in Brazil's Nordeste during the last 3000 years based on speleothem isotope records. Geophys Res Lett 39 (2012).

75 Schaan, D. P., Pärssinen, M., Ranzi, A. \& Piccoli, J. Geoglifos da Amazônia ocidental: Evidência de complexidade social entre povos da terra firme. Revista de Arqueologia 20, 67-82 (2007).

76 Saunaluoma, S. Pre-Columbian earthworks in the Riberalta region of the Bolivian Amazon. Amazônica-Revista de Antropologia 2 (2010).

77 Apaéstegui, J. et al. Hydroclimate variability of the northwestern Amazon Basin near the Andean foothills of Peru related to the South American Monsoon System during the last 1600 years. Clim. Past 10, 1967-1981, doi:10.5194/cp-10-1967-2014 (2014).

78 Kanner, L. C., Burns, S. J., Cheng, H., Edwards, R. L. \& Vuille, M. High-resolution variability of the South American summer monsoon over the last seven millennia: Insights from a speleothem record from the central Peruvian Andes. Quaternary Science Reviews 75, 1-10 (2013).

79 Erickson, C. L. in Time and Complexity in Historical Ecology: Studies in the Neotropical Lowlands (eds William Balée \& Clark L. Erickson) 235-278 (Columbia University Press, 2006).

80 Lombardo, U., May, J.-H. \& Veit, H. Mid- to late-Holocene fluvial activity behind preColumbian social complexity in the southwestern Amazon basin. The Holocene 22, 1035-1045, doi:10.1177/0959683612437872 (2012).

81 Mayle, F. E., Burbridge, R. \& Killeen, T. J. Millennial-scale dynamics of southern Amazonian rain forests. Science 290, 2291-2294 (2000).

82 Maezumi, S. Y., Whitney, B. S., Mayle, F. E., Gregorio de Souza, J. \& Iriarte, J. Reassessing climate and pre-Columbian drivers of paleofire activity in the Bolivian Amazon. Quaternary International, doi:https://doi.org/10.1016/j.quaint.2017.11.053 (2017).

83 Abbott, M. B., Binford, M. W., Brenner, M. \& Kelts, K. R. A 3500 14C yr High-Resolution Record of Water-Level Changes in Lake Titicaca, Bolivia/Peru. Quaternary Research 47, 169-180 (1997).

84 Thompson, I. G., Mosley-Thompson, E., Bolzan, J. F. \& Koci, B. R. A 1500-Year Record of Tropical Precipitation in Ice Cores from the Quelccaya Ice Cap, Peru. Science 229, 971-973, doi:10.1126/science.229.4717.971 (1985).

85 Kolata, A. L. \& Ortloff, C. R. in Tiwanaku And Its Hinterland: Archaeology And Paleoecology On An Andean Civilization Smithsonian Series In Archaeological Inquiry 181-201 (Smithsonian Institution Press, 1996).

86 Eder, F. J. Breve descripción de las reducciones de Mojos. (J. Barnadas, 1985).

87 de Souza, J. G. et al. Pre-Columbian earth-builders settled along the entire southern rim of the Amazon. Nature Communications 9, 1125, doi:10.1038/s41467-018-03510-7 (2018).

88 Wortham, B. E. et al. Assessing response of local moisture conditions in central Brazil to variability in regional monsoon intensity using speleothem $87 \mathrm{Sr} / 86 \mathrm{Sr}$ values. Earth and Planetary Science Letters 463, 310-322, doi:https://doi.org/10.1016/j.epsl.2017.01.034 (2017).

89 Meggers, B. J. Environmental Limitation on the Development of Culture. American Anthropologist 56, 801-824 (1954).

90 Denevan, W. M. Pre-Spanish Earthworks in the Llanos de Mojos of Northeastern Bolivia. Revista Geográfica 33, 17-25 (1964).

91 deMenocal, P. B. Cultural Responses to Climate Change During the Late Holocene. Science 292, 667-673, doi:10.1126/science.1059287 (2001).

92 Hodell, D. A., Curtis, J. H. \& Brenner, M. Possible role of climate in the collapse of ancient Maya civilization. Nature 357, 391-394 (1995). 
93 Iriarte, J., DeBlasis, P., De Souza, J. G. \& Corteletti, R. Emergent Complexity, Changing Landscapes, and Spheres of Interaction in Southeastern South America During the Middle and Late Holocene. Journal of Archaeological Research, 1-63, doi:10.1007/s10814-016-9100-0 (2016).

94 Håkansson, N. T. \& Widgren, M. (Left Coast Press, Walnut Creek, CA, 2014).

95 Whitney, B. S. et al. Pre-Columbian raised-field agriculture and land use in the Bolivian Amazon. The Holocene 24, 231-241, doi:10.1177/0959683613517401 (2014).

96 Rodrigues, L., Lombardo, U. \& Veit, H. Design of pre-Columbian raised fields in the Llanos de Moxos, Bolivian Amazon: Differential adaptations to the local environment? Journal of Archaeological Science: Reports 17, 366-378, doi:https://doi.org/10.1016/j.jasrep.2017.11.023 (2018).

97 Levis, C. et al. How People Domesticated Amazonian Forests. Frontiers in Ecology and Evolution 5, 171 (2018).

98 Sheehan, O., Watts, J., Gray, R. D. \& Atkinson, Q. D. Coevolution of landesque capital intensive agriculture and sociopolitical hierarchy. Proceedings of the National Academy of Sciences, doi:10.1073/pnas.1714558115 (2018).

99 Earle, T. K. How chiefs come to power: the political economy in prehistory. (Stanford University Press, 1997).

100 Turchin, P. et al. Quantitative historical analysis uncovers a single dimension of complexity that structures global variation in human social organization. Proceedings of the National Academy of Sciences, doi:10.1073/pnas.1708800115 (2017).

101 Dark, K. R. Waves of time: long term change and international relations. (Continuum, 1998).

102 Johnson, N. Simply complexity: a clear guide to complexity theory. (OneWorld Publications, 2007).

103 Renfrew, C. in Transformations, Mathematical Approaches to Culture Change (eds Colin Renfrew \& K. L. Cooke) 481-506 (Academic Press, 1979).

104 Redman, C. L. \& Kinzig, A. P. Resilience of past landscapes: resilience theory, society, and the longue durée. Conservation Ecology 7, 14 (2003).

105 Redman, C. L. Resilience Theory in Archaeology. American Anthropologist 107, 70-77 (2005).

106 MICHELLE, H. et al. Social Transformation and Its Human Costs in the Prehispanic U.S. Southwest. American Anthropologist 110, 313-324, doi:doi:10.1111/j.15481433.2008.00041.x (2008).

107 Flores, B. M. et al. Floodplains as an Achilles' heel of Amazonian forest resilience. Proceedings of the National Academy of Sciences 114, 4442-4446, doi:10.1073/pnas.1617988114 (2017).

108 Gomes, D. C. Cronologia e Conexões Culturais na Amazônia: as Sociedades Formativas na Região de Santarém, PA. Revista de Antropologia 54, 268-314 (2011).

109 Quinn, E. Excavating "Tapajó" ceramics at Santarém: their age and archaeological context PhD thesis, University of Illinois at Chicago, (2004).

110 Woods, W. I. et al. (Springer, Dordrecht, 2009).

111 McMichael, C. H. et al. Predicting pre-Columbian anthropogenic soils in Amazonia. Proceedings of the Royal Society of London B: Biological Sciences 281, 20132475 (2014).

112 Glaser, B. \& Woods, W. I. (Springer, Berlin, 2004).

113 Schmidt, M. J. \& Heckenberger, M. J. in Amazonian Dark Earths: Wim Sombroek's vision (eds W. I. Woods et al.) 163-191 (Springer, 2009).

114 Glaser, B. Prehistorically modified soils of central Amazonia: a model for sustainable agriculture in the twenty-first century. Philosophical Transactions of the Royal Society B: Biological Sciences 362, 187-196, doi:10.1098/rstb.2006.1978 (2007). 
115 Neves, E. G., Petersen, J. B., Bartone, R. \& Augusto Da Silva, C. in Amazonian dark earths: origins, properties, management (eds J. Lehmann, D. C. Kern, B. Glaser, \& W. I. Woods) 29-50 (Kluwer Academic Publisher, 2004).

116 Levis, C. et al. Historical Human Footprint on Modern Tree Species Composition in the Purus-Madeira Interfluve, Central Amazonia. PLOS ONE 7, e48559, doi:10.1371/journal.pone.0048559 (2012).

117 ter Steege, H. et al. Hyperdominance in the Amazonian Tree Flora. Science 342, doi:10.1126/science.1243092 (2013).

118 Kunen, J. L. Ancient Maya Life in the Far West Bajo: Social and Environmental Change in the Wetlands of Belize. (The University of Arizona Press, 2004).

119 Rodrigues, L. et al. An insight into pre-Columbian raised fields: the case of San Borja, Bolivian lowlands. SOIL 2, 367-389, doi:10.5194/soil-2-367-2016 (2016).

120 Balée, W. L. Footprints of the forest: Ka'apor ethnobotany - the historical ecology of plant utilization by an Amazonian people. (Columbia University Press, 1994).

121 Arroyo-Kalin, M. The Amazonian formative: crop domestication and anthropogenic soils. Diversity 2, 473-504 (2010).

122 Woods, W. I., Denevan, W. M. \& Rebellato, L. in Soils, climate and society: archaeological investigations in ancient America (eds J. D. Wingard \& S. E. Hayes) 120 (University Press of Colorado, 2013).

123 Kaniewski, D. et al. Environmental Roots of the Late Bronze Age Crisis. PLOS ONE 8, e71004, doi:10.1371/journal.pone.0071004 (2013).

124 Drake, B. L. The influence of climatic change on the Late Bronze Age Collapse and the Greek Dark Ages. Journal of Archaeological Science 39, 1862-1870, doi:https://doi.org/10.1016/j.jas.2012.01.029 (2012).

125 Cline, E. H. 1177 BC: the year civilization collapsed. (Princeton University Press, 2015).

126 Dillehay, T. D. et al. Cultivated wetlands and emerging complexity in south-central Chile and long distance effects of climate change. Antiquity 81, 949-960, doi:10.1017/S0003598X00096034 (2015).

127 Dull, R. A. et al. The Columbian encounter and the Little Ice Age: Abrupt land use change, fire, and greenhouse forcing. Annals of the Association of American Geographers 100, 755-771 (2010).

128 Nevle, R. J., Bird, D. K., Ruddiman, W. F. \& Dull, R. A. Neotropical human-landscape interactions, fire, and atmospheric $\mathrm{CO} 2$ during European conquest. The Holocene 21, 853-864, doi:10.1177/0959683611404578 (2011).

129 Power, M. J. et al. Climatic control of the biomass-burning decline in the Americas after ad 1500. The Holocene 23, 3-13, doi:10.1177/0959683612450196 (2012). 